\title{
GLACIOLOGICAL BODIES: AUSTRALIAN VISIONS OF THE ANTARCTIC ICE SHEET
}

ALESSANDRO ANTONELLO

\section{Abstract}

Building upon work in environmental history and the history of science that has critically investigated the relationships between humans and ice, this article approaches the history of the Antarctic ice sheet through the particular experiences, practices and ideas of Australian glaciologists between the late 1940s and late 1980s. It seeks to understand the co-constitution of glaciological bodies-that is, the ways in which the work and search for standing and authority of individual scientists and scientific and political institutions (both scholarly and governmental) has also constituted our knowledge and sensibilities regarding the Antarctic ice sheet, the largest body of ice on Earth. This article reveals the origins of glaciology in Australia in both the heroic and nationalist stance of Douglas Mawson and others, as well as the German geographical and meteorological research traditions of Fritz Loewe. It continues by exploring the tensions between traditions of geographical research embodied by Loewe and cutting-edge developments in computational power and modelling the ice sheet emerging in the 1960s. It also demonstrates how Australian glaciologists had to navigate both the international demands of the discipline of glaciology alongside the demands of their paymasters in the Australian Government regarding territory and sovereignty in Antarctica. Thus, this article illuminates some of the multiple visions of the Antarctic ice sheet in the second half of the twentieth century, and the necessity of understanding its constitution in environmental and scientific thought by many actors.

Keywords: Antarctica, glaciology, Australia, geopolitics

\section{Introduction}

Since the late 1940s, Australia—and more specifically Melbourne and, from the late 1980s, Hobart-has become home to a small but internationally influential community of glaciologists studying the Antarctic ice sheet. This community of glaciologists has worked within national and international structures, and has contributed not only in terms of science to an understanding of the Antarctic ice sheet, but has also shaped environmental sensibilities about the Antarctic and the place of ice in the global environment. 
This article is about developing environmental and scientific conceptions of the Antarctic ice sheet through the trajectory of the science of glaciology in Australia, from the period immediately following the Second World War to the early 1990s. It investigates 'glaciological bodies' in a multiple sense, not only the Antarctic ice sheet itself, but also the individual human bodies and the national and international institutional bodies that have explored and researched the ice, as well as the more amorphous and ever-changing body of knowledge that is the discipline of glaciology. The 'bodies' primarily investigated here are the Australian Antarctic Division, the meteorology department at the University of Melbourne, which housed or fed into the division's glaciology program for many years, and three individual scientists, Fritz Loewe, Uwe Radok and Bill Budd. It is not a comprehensive narrative of scientific programs, but an attempt to understand the co-constitution of glaciological bodies, especially the establishing of authority over and for the ice sheet and its changing 'natures' over a period of development in glaciological and environmental knowledge.

At a general level, this article participates in the literature that historicises the relationships between humans and ice. Though ice seems so singular a substance, it manifests in complex and various ways on the earth. The largest bodies of ice, the Antarctic and Greenland ice sheets, are quite distinct from small mountain glaciers, and each have developed and reacted in different ways to climate change over both geological time and more recently. Likewise, there is no single human approach to ice. ${ }^{1}$ An historical analysis of what humans do in relation to ice, what they think of it and expect in their relations with it, can illuminate the 'cryo-historical moment' that we live in, to use Sverker Sörlin's label for this moment in which humans are forcing the retreat of ice globally. ${ }^{2}$ Given the centrality of ice to contemporary global environmental imaginaries, it is necessary to ask how knowledge and sensibilities related to glaciers are produced and circulated, and how they become credible and authoritative. ${ }^{3}$

\footnotetext{
1 This article is based upon work supported by the US National Science Foundation under grant \#1253779. It began while I was a postdoctoral fellow at the University of Oregon, and I thank Mark Carey for our discussions on the history of glaciology and ice while I was there. My thanks to Ruth Morgan and the reviewers for their critical and helpful comments, as well as to the always helpful staff of the National Archives of Australia (NAA) and the University of Melbourne Archives. Two central works in the human histories of ice crystallise this: Julie Cruikshank, Do Glaciers Listen? Local Knowledge, Colonial Encounters, and Social Imagination (Vancouver: University of British Columbia Press, 2005) and Mark Carey, In the Shadow of Melting Glaciers: Climate Change and Andean Society (New York: Oxford University Press, 2010).

2 Sverker Sörlin, 'Cryo-History: Narratives of Ice and the Emerging Arctic Humanities', in The New Arctic, ed. Birgitta Evengård, Joan Nymand Larsen and Øyvind Paasche (Cham: Springer, 2015), 327-8.

3 Mark Carey, 'The History of Ice: How Glaciers Became an Endangered Species', Environmental History 12 (2007): 497-527, doi.org/10.1093/envhis/12.3.497; Mark Carey, M. Jackson, Alessandro Antonello and Jaclyn Rushing, 'Glaciers, Gender, and Science: A Feminist Glaciology Framework for Global Environmental Change Research', Progress in Human Geography 40, no. 6 (2016): 770-93, doi.org/10.1177/0309132515623368.
} 
This article takes Australian glaciology as a worthwhile lens through which to consider the history of ideas of the Antarctic ice sheet, and human-ice histories more generally, for three reasons. First, it continues the now well-established idea in the history of science that there is no 'view from nowhere', that scientific claims to universal authority and truth need to be understood as emerging from particular times and places. ${ }^{4}$ This is especially germane in the context of Antarctica, where scientists, their institutions and disciplines have been central agents in the geopolitical contest over territory and space played out among several states over the course of the twentieth century. ${ }^{5}$ Second, the science of glaciology has not historically been a well-populated discipline, being much smaller than many other sciences. The Australian glaciologist Bill Budd listed only 11 'specialising centres' in Antarctic glaciology in 1970, which included the University of Melbourne and centres in Britain, the United States, France, Japan and the Soviet Union-even taking into account Arctic and alpine glaciology would only have added a few more centres. ${ }^{6}$ Analysing the Australian story of glaciology is therefore an important window into this discipline. Third, and related to both these factors of size and the 'place' of science, is the differentiation between the glaciological centres. Though there were certainly overlapping technological and field practices, and of course the theoretical and conceptual core of the discipline, each centre of glaciological expertise had different ways of approaching the Antarctic ice sheet (and glaciers more generally). ${ }^{7}$ Several institutions have already been well analysed in this

4 Steven Shapin, 'Placing the View from Nowhere: Historical and Sociological Problems in the Location of Science', Transactions of the Institute of British Geographers 23, no. 1 (1998): 5-12, doi.org/10.1111/j.00202754.1998.00005.x; David N. Livingstone, Putting Science in Its Place: Geographies of Scientific Knowledge (Chicago: University of Chicago Press, 2003). For this type of analysis on glaciology specifically, see Diarmid A. Finnegan, 'The Work of Ice: Glacial Theory and Scientific Culture in Early Victorian Edinburgh', British Journal for the History of Science 37, no. 1 (2004): 29-52, doi.org/10.1017/S0007087403005314.

5 Simone Turchetti, Simon Naylor, Katrina Dean and Martin Siegert, 'On Thick Ice: Scientific Internationalism and Antarctic Affairs, 1957-1980', History and Technology 24, no. 4 (2008): 351-76, doi.org/ 10.1080/07341510802357419; Peder Roberts, The European Antarctic: Science and Strategy in Scandinavia and the British Empire (New York: Palgrave Macmillan, 2011).

6 W. Budd, 'IAGP Meeting, Paris, May 1970. Brief Notes', c. April-May 1970. B1387, 1986/576 Part 2, NAA. On the historical divisions between North America and Europe within the discipline until the 1990s, see W. Tad Pfeffer, The Opening of a New Landscape: Columbia Glacier at Mid-Retreat (Washington, DC: American Geophysical Union, 2007), 33, note 12 and 36, note 18.

7 The historiography on glaciology and its various iterations and cognate disciplines is uneven in coverage. Gordon Fogg treats it poorly in his history of Antarctic science, saying it is 'a minor branch of physics', if important in Antarctica: G. E. Fogg, A History of Antarctic Science (Cambridge: Cambridge University Press, 1992), 274; on Hans Ahlmann, an important mid-century glaciologist, see Sverker Sörlin, 'Narratives and Counter-Narratives of Climate Change: North Atlantic Glaciology and Meteorology, c.1930-1955', Journal of Historical Geography 35 (2009): 237-55, doi.org/10.1016/j.jhg.2008.09.003; Sverker Sörlin, 'The Global Warming That Did Not Happen: Historicizing Glaciology and Climate Change', in Nature's End: History and the Environment, ed. Sverker Sorlin and Paul Warde (Basingstoke: Palgrave Macmillan, 2009), 93-114; on the Norwegian-British-Swedish Expedition, see Roberts, The European Antarctic; on traversing and seismic sounding during the International Geophysical Year, see Dian Olson Belanger, Deep Freeze: The United States, the International Geophysical Year, and the Origins of Antarctica's Age of Science (Boulder, CO: University Press of Colorado, 2006) and Simon Naylor, Katrina Dean and Martin Siegert, 'The IGY and the Ice Sheet: Surveying Antarctica', Journal of Historical Geography 34, no. 4 (2008): 574-95, doi.org/10.1016/j.jhg.2008.07.001; on Alaskan glaciers, see Pfeffer, The Opening of a New Landscape; on the changes and continuities in engaging with the Antarctic ice sheet, see Alessandro Antonello, 'Engaging and Narrating the Antarctic Ice Sheet: The History of an Earthly Body', Environmental History 22, no. 1 (2017): 77-100, doi.org/10.1093/envhis/emw070. 
regard, including the particular approach to aerial radio-echo sounding of Antarctica in the 1960s and 1970s by the Scott Polar Research Institute of the University of Cambridge, as well as the various state and military expeditions to Greenland during the mid-twentieth century. ${ }^{8}$ By tracing the Australian experience of the Antarctic ice sheet alongside other national and transnational traditions and lineages, this article draws out the complex facets of the ice sheet's coming into scientific knowledge and environmental sensibilities.?

What emerges from the particular stories told here are the multiple, sometimes competing, visions of the Antarctic ice sheet and the associated institutions and individuals. Not simply one giant piece of ice, human interactions with the Antarctic ice sheet have constituted it as regionally variable and particular, as a field of national sovereignty and as a field of international cooperation, as a subject of virtual modelling and of localised embodiment and territoriality. As knowledge has grown over the decades, there have been fluctuations in visions of the ice sheet, between an extreme environment to be endured (primarily bodily, but also geopolitically) or as an intellectual and abstract environment to be understood and mastered. The small body of Australian glaciologists have taken a particular route through these ideas, searching for a delicate balance and mix of both individual, national and institutional standing in relation to their disciplines and professions, and in relation to Antarctic science and politics.

\section{Inheritance}

Australia has been a continent without glaciers for a long period of geological time. The Australian empire, however, gained glaciers and a wedge of ice sheet in 1933, when the Commonwealth of Australia asserted a territorial claim to just over 40 per cent of the Antarctic continent, which it named the Australian Antarctic Territory. The acquisition of this slice of the Antarctic ice sheet did not demand glaciologists per se; yet, with other scientists, glaciologists would become important agents of Australian sovereignty as well as conducting fundamental research. Between 1933 and the end of the Second World War, however, the Australian Government sent no official expeditions to explore the newly claimed slice of Antarctica.

8 On the radio-echo sounding work developed by the Scott Polar Research Institute, see Simone Turchetti, Katrina Dean, Simon Naylor and Martin Siegert, 'Accidents and Opportunities: A History of the Radio EchoSounding of Antarctica, 1958-79', British Journal of the History of Science 41, no. 3 (2008): 417-44, doi.org/10.1017/ S0007087408000903, and Katrina Dean Simon Naylor, Simone Turchetti and Martin Siegert, 'Data in Antarctic Science and Politics', Social Studies of Science 38, no. 4 (2008): 571-604, doi.org/10.1177/0306312708090693; on German, French, US and Danish efforts in Greenland, see Janet Martin-Nielsen, Eismitte in the Scientific Imagination: Knowledge and Politics at the Center of Greenland (New York: Palgrave Macmillan, 2013).

9 There are several scientific reviews of Australia's glaciological program by actors within it: William F. Budd, 'The Antarctic Ice Sheet', in Australian Antarctic Science: The First 50 Years of Anare, ed. Harvey J. Marchant, Desmond J. Lugg and Patrick G. Quilty (Kingston, Tasmania: Australian Antarctic Division, 2002), 309-90; Ian Allison, 'Sea-Ice, Ice Shelves and Icebergs', in Australian Antarctic Science, ed. Marchant, Lugg and Quilty, 391-426. 
When the Australian Government resolved in the post-war years to send an official expedition to Antarctica to demonstrate its sovereign intentions (neglected in the context of economic depression and war), it did so with two inheritances germane to glaciology and ice. Though parts of the Antarctic ice sheet had been seen or travelled upon by 1945, it was still a great unknown. First stepped upon by humans in 1903, there had only been limited work by a few expeditions - basic facts about its extent, including its depth, were unknown. On top of this knowledge deficit, there were two other inheritances. On the one hand was the nationalist and imperialist inheritance stretching back into the late nineteenth century and embodied in the hero of the Australian nation, Douglas Mawson. On the other hand, and rather fortuitously, was a geographical and scientific inheritance from Germany (and Europe more generally) embodied in Fritz Loewe.

Australians had become interested in Antarctica in the nineteenth century, when sealers and whalers plied the Southern Ocean, and when major explorers came through its ports, especially Hobart, Melbourne and Sydney. ${ }^{10}$ Australians also played a significant part in the 'Heroic Era' of Antarctic exploration at the beginning of the twentieth century, most notably in the figure of the geologist Douglas Mawson, who travelled with Ernest Shackleton's Nimrod expedition of 1907-09 and later led the Australasian Antarctic Expedition between 1911 and 1914-but also included the geologist Edgeworth David and the geographer, geomorphologist and geologist Griffith Taylor, who had done much work on glacial geology during his time on Robert Scott's Terra Nova expedition, especially in the Dry Valleys during 1911.11 Though none were glaciologists, each was interested in the effects of ice and water on landscapes.

Mawson was a particularly forceful advocate for a 'permanent connection' between Australia and Antarctica, drawing on strands of nationalism, imperialism, economic exploitation and scientific research to make his case. Indeed, Mawson was the leading figure in securing a place in the Australian imagination for Antarctica, through his own expeditionary exploits in the region, as well as through active lobbying of government for funding of scientific research and expeditions. One outcome of the cultivation of these interests and connections was that the Commonwealth of Australia made a territorial claim in Antarctica in 1933. This claim covers the region between $60^{\circ}$ south latitude and the South Pole ( $90^{\circ}$ south), and between $160^{\circ}$

10 R. W. Home, Sara Maroske, A. M. Lucas and P. J. Lucas, 'Why Explore Antarctica?: Australian Discussions in the 1880s', Australian Journal of Politics and History 38, no. 3 (1992): 386-413, doi.org/10.1111/j.1467-8497.1992. tb00682.x; Marie Kawaja and Tom Griffiths, “Our Great Frozen Neighbour”: Australia and Antarctica before the Treaty, 1880-1945', in Australia and the Antarctic Treaty System: 50 Years of Influence, ed. Marcus Haward and Tom Griffiths (Sydney: UNSW Press, 2011), 9-47.

11 Philip Ayres, Mawson: A Life (Melbourne: Miegunyah Press, 1999); David Branagan, T. W. Edgeworth David: A Life: Geologist, Adventurer, Soldier and 'Knight in the old brown hat' (Canberra: National Library of Australia, 2005); Carolyn Strange and Alison Bashford, Griffith Taylor: Visionary, Environmentalist, Explorer (Canberra: National Library of Australia, 2008); Adrian Howkins, 'Taylor's Valley: What the History of Antarctica's "Heroic Era" Can Contribute to Contemporary Ecological Research in the McMurdo Dry Valleys', Environment and History 22, no. 1 (2016): 3-28, doi.org/10.3197/096734016X14497391602125. 
and $45^{\circ}$ east longitudes-interrupted by the French territorial claim in Adélie Land between $142^{\circ}$ and $136^{\circ}$ east - a vast stretch of land and ice that was breathtaking in its presumptuousness, given that parts of its coastline and the bulk of the ice interior had never been visited or seen by any Australian or British explorer. ${ }^{12}$

Though Australia made its territorial claim in 1933, in terms of international law it did little to 'perfect' or uphold its rights until after the Second World War. In the context of post-war national reconstruction and development, the national government instituted the Australian National Antarctic Research Expeditions (ANARE) and created an Antarctic Division in the Department of External Affairs; it was based in Melbourne until the early 1980s. ${ }^{13}$ The initial tasks of ANARE were, first, to effect the administration of Australia's Antarctic possessions, which included not only part of the continent but also the subantarctic Macquarie (south of Tasmania) and Heard (in the south-east Indian Ocean) islands. The administration and effective occupation of these territories was increasingly seen as necessary given the fact that British territorial claims in Antarctica were contested, sometimes physically and violently, by Argentina and Chile. ${ }^{14}$

The second major task of ANARE was to form and carry out a scientific program. In part, this was also a tool of effective occupation. Despite its clear political and diplomatic uses, the scientific program instituted was connected to existing Australian research interests-notably in its concentration on meteorology and atmospheric physics-as well as being run by scientists. The scientific program was developed by Phillip Law, who was the Antarctic Division's first scientific officer in 1947, and soon after its director, leading it until $1966 .{ }^{15}$ The earliest scientific plans emphasised meteorology (weather matters having been a central element in long-standing ideas about Australian-Antarctic connections) and other geophysical sciences, like ionospheric research (which had existing research programs in Australia). Because of the sense that glaciology was not as economically promising or practically useful as these other disciplines, it was not part of ANARE's early plans. ${ }^{16}$

Phillip Law was conscious of glaciology, though it was not a pressing concern for him. It seems that he had resolved by 1949 for a young University of Melbournetrained physicist, John Jelbart, to initiate glaciological research-Law thought all he needed was a 'good mathematician' to fill the job, though Jelbart also seemed to

12 Marie Kawaja, 'The Politics and Diplomacy of the Australian Antarctic, 1901-1945' (PhD diss., The Australian National University, 2010).

13 Generally, see Tim Bowden, The Silence Calling: Australians in Antarctica 1947-97 (St Leonards: Allen \& Unwin, 1997).

14 Klaus Dodds, Pink Ice: Britain and the South Atlantic Empire (London: I. B. Tauris, 2002); Adrian Howkins, Frozen Empires: An Environmental History of the Antarctic Peninsula (New York: Oxford University Press, 2017).

15 Bowden, The Silence Calling.

16 'Appendix B. Programme of scientific work for the Australian Antarctic expedition', Cabinet Submission 1275B, 15 April 1947. A2700, 1275B, NAA. 
fit the image of a young, adventurous, outdoorsy type favoured by Law. ${ }^{17}$ This may have led to Jelbart's joining the Norwegian-British-Swedish Antarctic Expedition in 1950 to be exposed to Swedish-led glaciological research; sadly, Jelbart would die on that expedition, forestalling the decisive initiation of glaciological research in the early 1950s. ${ }^{18}$ Following this, even though Law proposed seismic sounding to determine the ice sheet's depth in the early 1950s, this research proposal did not eventuate in the short term because of cost-cutting; it was classified as 'long-term' rather than immediately pressing, and it was thought that measurements could be taken by non-specialists. ${ }^{19}$ It is worth noting that glaciology was still a small discipline in other countries: the American glaciologist Dick Goldthwait could report only 40 academics in the United States working on glaciology in 1956, and worldwide membership of the British Glaciological Society (soon to be the International Glaciological Society) was between 300 and 400 through the 1950s, a number that included many geologists and geomorphologists. ${ }^{20}$

If Law had difficulties in launching the field research component of a glaciological program, he was lucky in finding an institutional and intellectual home for glaciology in Australia. Law had only to look to the meteorology department at the University of Melbourne, and its leading figure, the meteorologist and glaciologist Loewe. With Loewe, Law tapped into a different inheritance of scientific and geographical research and a separate strand of early twentieth-century polar heroism.

Loewe was born in 1895 in Berlin, and his university training there was in geography, with a good deal of meteorology. ${ }^{21}$ Following work with the Potsdam Meteorological Observatory and the Prussian Meteorological Service, Loewe became meteorologist on Alfred Wegener's expedition to Greenland in 1930-31. Wegener was among the leading German earth scientists of the era, and was the first scientist to advance a significant theory of continental drift to explain the earth's geological and tectonic structures. Among Wegener's plans for the 1930-31 expedition was to occupy a scientific base at Eismitte in the middle of the Greenland ice sheet over the winter-the first such mid-ice sheet occupation of its kind. Loewe, owing

\footnotetext{
17 Bowden, The Silence Calling.

18 Phillip Law, 'Obituary: John Ellis Jelbart', Polar Record 6, no. 45 (1953): 698-9; and 'Minutes of meeting of Physics Sub-Committee' [of the Executive Planning Committee], 6 December 1950. A1838, 1495/3/4/1 Part 1, NAA.

19 Appendix A, Cabinet submission, 13 January 1953. A1838, 1495/3/2/1/1/ Part 1, NAA; R. G. Casey, Letter to R. G. Menzies, 20 January 1953. A1838, 1495/3/2/1/1/ Part 1, NAA; P. G. Law, 'Future Operations of the ANARE, 1959-1964', Paper (58) 11. A1838, 1495/3/4/1 Part 4, NAA.

20 Janet Martin-Nielsen, “An Orgy of Hypothesizing”: The Construction of Glaciological Knowledge in Cold War America', in Exploring Ice and Snow in the Cold War, ed. Christian Kehrt, Franziska Torma and Julia Herzberg (New York and Oxford: Berghahn Books, forthcoming); Fae L. Korsmo, 'Glaciology, the Arctic, and the US Military, 1945-58', in New Spaces of Exploration: Geographies of Discovery in the Twentieth Century, ed. Simon Naylor and James R. Ryan (London: I. B. Tauris, 2009); 'Circulation of the Journal of Glaciology', Ice no. 5 (January 1960).

21 For some sense of the scope of scientific education in Berlin before Loewe's time, see Mott T. Greene, Alfred Wegener: Science, Exploration, and the Theory of Continental Drift (Baltimore, MD: Johns Hopkins University Press, 2015), Chap. 3.
} 
to severe frostbite that led to the amputation of his toes, unexpectedly spent the winter at Eismitte; Wegener died while returning to the coast. ${ }^{22}$ It was with Wegener that Loewe became familiar with seismic sounding of ice depth in addition to his meteorological expertise, as Wegener's Greenland expedition was dispatched, in part, to test that technique. ${ }^{23}$ Within two years of his return to Germany and with the rise of the Nazis to government and their anti-Semitic policies, Loewe lost his civil service position in 1933 and was arrested and jailed. Following an amnesty, he left Germany in 1934 for a short-term position at the Scott Polar Research Institute, where he worked until 1937. From there he was sponsored by Raymond Priestley, Vice-Chancellor of the University of Melbourne and an Antarctic exploration veteran, to join the university to initiate a meteorology program. At Melbourne, he established the university's meteorology department in 1939, the first of its kind in Australia. ${ }^{24}$ He became a well-known figure in Melbourne, with the Argus describing him in 1950 as 'Melbourne's No. 1 weather wizard' and a 'quiet philosopher'. ${ }^{25}$

Loewe was part of early ANARE work and institution-building. He travelled on the unsuccessful voyage of the Wyatt Earp to Antarctica in 1947-48, and was Australia's official representative on the French Antarctic expeditions of 1949-50 and 1951-52 - the published results of his fieldwork with the French expedition were among the earliest substantial post-war contributions to the field. ${ }^{26}$ Yet, despite these early efforts, glaciology, without an already established research group in Australia and without an immediately compelling economic justification, remained in the shadows of other disciplines, and the ice sheet in the shadow of other geophysical phenomena. Even in 1960, Loewe could still comment on the seemingly marginal position of glaciology. ${ }^{27}$

As a trained meteorologist, Loewe's approach to the Antarctic ice sheet was partly meteorological. In fact, he had already treated the Greenland ice sheet in the same way in the 1930 s. $^{28}$ Loewe's initial fieldwork in Antarctica aimed to measure the snow accumulation and related wastage by evaporation, wind and iceberg calving from the ice sheet. Like most other glaciological work at the time, Loewe was concerned with amassing as much data as possible. He also ventured to suggest a bigger picture, advancing one of the first estimates of the mass balance of the

22 See Martin-Nielsen, Eismitte, 20-38; David Thomas Murphy, German Exploration of the Polar World: A History, 1870-1940 (Lincoln, NE, and London: University of Nebraska Press, 2002), Chap. 4.

23 Greene, Alfred Wegener, Chaps 19 and 20.

24 Peter Schwerdtfeger, 'Fritz Loewe-1896-1974', Journal of Glaciology 14, no. 70 (1975): 191-3; Mark Richmond, 'Loewe, Fritz Philipp (1895-1974)', in Australian Dictionary of Biography (Melbourne: Melbourne University Press, 2000).

25 The Argus, 18 May 1950, 6.

26 F. Loewe, 'Contributions to the Glaciology of the Antarctic', Journal of Glaciology 2, no. 19 (1956): 657-65.

27 F. Loewe, Letter to K. Bullen, 31 October 1960. Loewe Collection Acc. 88/160, Box 52. University of Melbourne Archives.

28 F. Loewe, 'The Greenland Ice Cap as Seen by a Meteorologist', Quarterly Journal of the Royal Meteorological Society 62, no. 266 (1936): 359-77, doi.org/10.1002/qj.49706226601. 
ice sheet, which suggested it might be growing. In the process, he also engaged with some of the broader glaciological concerns of the time, particularly noting the global warming of the climate and the recession of glaciers. ${ }^{29}$ Though some basic theoretical and conceptual constructs as well as data were emerging by the early 1950s, the Antarctic ice sheet remained a vast near-unknown entity.

Additionally, Loewe's approach to meteorology and to the ice sheet was as a geographer. While German geographical thought was somewhat in flux and contested during Loewe's university years, it was nevertheless a discipline insistent on broadly understanding physical environments at local and regional scales-there was some contest as to what place humans had in this picture. ${ }^{30}$ His 1946 description of the ideal traits for Antarctic fieldwork might be read through this tradition: 'scientific initiative, sound training of a not too specialised kind, interest in diverse branches of science and the ability to recognise and tackle scientific problems as they arise in the field'. ${ }^{31}$ His sentiments in 1960, shortly after his retirement, are also illuminating: he voiced his 'regret at the widening gap between geography and meteorology', that students were ignorant 'about the features of the earth on which they live and of which the atmosphere after all forms only a shell of insignificant thickness' - and that young meteorologists should 'look earthward and get a sound knowledge of the solid earth, and of man as its inhabitant'. Loewe also expressed the frustrations of older meteorologists, who had 'become less and less familiar with the sensual impressions of the atmosphere', relying not on their senses, but on 'weather maps produced by ticking robots'. He went on to say ' $[\mathrm{t}]$ here would perhaps be a smaller number of "angry young men" in meteorology if they had to go out in a blizzard and had to battle with the forces of nature before reducing them to the soulless numbers of a code'. ${ }^{32}$

Loewe's influence was limited by the small scale of the glaciological program in the 1950s. There was only one masters student-Malcolm Mellor-in the whole decade to conduct a glaciological project, though his thesis on the subject of Antarctica's mass balance (a question of interest to Loewe) did manifest certain tropes and narratives of individual travel to the ice sheet. ${ }^{33}$ Loewe's ideas articulated an older and passing approach to the polar ice sheets, one deeply embodied and local — that the Antarctic ice sheet was a real site for singular effort in the field collecting data. ${ }^{34}$

29 F. Loewe, 'Notes Concerning the Mass Budget of the Antarctic Inland Ice', in Antarctic Meteorology: Proceedings of the Symposium Held in Melbourne, February 1959 (New York: Pergamon, 1960), 361-69; The Argus, 18 May 1950,6 .

30 Gary S. Dunbar, ed., Modern Geography: An Encyclopaedic Survey (New York: Garland, 1991), 41-4.

31 F. Loewe, 'Some Considerations Regarding an "International Polar Year" for the Southern Hemisphere', May 1946. Loewe Collection Acc. 88/160, Box 50, University of Melbourne Archives.

32 F. Loewe, Meteorology in Retrospect (Melbourne: University of Melbourne, Meteorology Department, 1960).

33 Malcolm Mellor, 'A Study of Factors Governing the Mass Economy of Antarctica' (MSc diss., University of Melbourne, 1959).

34 There are resonances here with Sörlin's account of Ahlmann's ‘microgeography of authority': Sörlin, 'The Global Warming That Did Not Happen'. 
Successive generations would not, indeed could not, fully take up such an approach, basically by virtue of the fact that it seemed so incommensurable with the size of the ice sheet.

\section{'Late in the field'}

Great field efforts during the 1950s — especially the seismic sounding program during the International Geophysical Year (IGY) of 1957-58-meant that knowledge of the Antarctic ice sheet in 1960 was significantly developed compared to only a decade before. Much of this work was done by scientists from the United States and the Soviet Union, who could marshal the significant (and expensive) infrastructure and instruments to carry out such a demanding research program. Glaciologists were beginning to appreciate the ice sheet's great depths across its spatial extent, and had discovered how it was depressing and resting upon bedrock in places well below sea level. This new knowledge had been achieved through 'big science' and varying degrees of international cooperation and planning.

While Loewe's approach to the ice at this time seemed to valorise individualistic and physical presence on the ice, his students and successors came to the ice in larger groups, with the mindset of big science, both national and international. Loewe was already well advanced in his career by the 1950s, and retired in 1959. From the mid1940s he taught increasing numbers of meteorological students, especially those destined for the Bureau of Meteorology, which had its headquarters in Melbourne. One student, Uwe Radok, however, became something of a protégé, especially in matters of glaciological research.

Radok was born in Königsberg (Kaliningrad) in 1916, and after his initial studies there became a student in 1934 at the Technische Hochschule in Munich, where he studied mechanical engineering. He took a job as an engineering draughtsman in Glasgow, but was interned at the beginning of the Second World War. He was transferred to Australia in the Dunera and arrived for internment in September 1940. He remained interned until 1942 when he was released and served in the Australian army until 1944. He began corresponding with Loewe whilst interned in 1940 and subsequently went to work with him in 1942 as part of his military duties. In 1950, he was appointed lecturer in the Department of Meteorology at the University of Melbourne, was promoted to senior lecturer in 1957 and became reader-in-charge in 1961. A 1968 profile of Radok noted: 'He arouses and maintains interest as much by letter-writing as by rapid conversation and pungent comment', as well as being 'famous for his sartorial splendour' while on field excursions, 'best described as "International War Surplus", featuring an irregular camouflage design'. 35 
Radok was the driving intellectual and programmatic force behind Australian glaciology from 1960. Radok described Australia as being 'late in the field', yet he was confident that Australians could do focused work to illuminate the glaciological elements of 'Antarctica as a whole'. ${ }^{36}$ Because Australian glaciology was charged, in part, with maintaining Australian sovereignty, it claimed expansive horizons and projects for its research. As Radok put it in 1963:

The regions of the three ANARE stations on the Antarctic continent exemplify the full range of its features, from fast ice streams embedded in the unbroken continental ice sheet (Wilkes) through mountain chains ringing a major ice shelf (Mawson) to a de-glaciated oasis (Davis). The problems and opportunities facing Australian glaciologists are therefore those of Antarctica as a whole. ${ }^{37}$

With Radok as one of their instructors, Australian students began to conduct more extensive glaciological studies in Antarctica, though always on a scale commensurate with Australia's limited resources. They conducted traverses from Mawson, Wilkes and Davis stations, taking seismic soundings, digging pits, boring holes, measuring temperatures and analysing firn stratigraphy and structure (firn being the intermediate stage in snow's transformation into ice). ${ }^{38}$ Radok himself led micrometeorological investigations, studying the way snow drifted in several locations, including at American stations. A particularly significant early investigation was the multi-season field study of the Amery Ice Shelf between 1962 and 1965; a small team camped upon the ice shelf during the summer seasons, and the results by 1965-66 were the most extensive for any ice shelf at the time, and remained so until the late 1970s. ${ }^{39}$ From 1964, Australian glaciologists also took advantage of the small ice cap near Casey Station to advance basic glaciological work. The Wilkes ice cap_officially known as Law Dome after 1970_-was an ice sheet in miniature, separated from the main East Antarctic ice sheet, and a useful microcosm for studying ice dynamics in general-this work yielded strong published results by the end of the decade. ${ }^{40}$ This Australian research contrasted, for example, with American work in Greenland in the 1950s, which saw an 'engineering approach', looking for 'practical use of snow and ice' in turning the Greenland ice sheet into a military stage for continental defence during the Cold War. ${ }^{41}$

While this fieldwork advanced, the meteorology department at the University of Melbourne pushed ahead in the use of a computer for both meteorological and glaciological studies. In 1955-56, the University of Melbourne received a computer

36 U. Radok, 'Glaciology in Australian Antarctica', Amended Version, 13 May 1963. B1387, 1986/576 Part 1, NAA.

37 U. Radok, 'Glaciology in Australian Antarctica', Amended Version, 13 May 1963. B1387, 1986/576 Part 1, NAA.

38 See U. Radok, 'Fieldwork Australia', Ice, no. 15 (August 1964): 2.

39 Budd, 'The Antarctic Ice Sheet', 320-1.

40 Ibid., 322-5.

41 Martin-Nielsen, “'An Orgy of Hypothesizing”. 
from the Commonwealth Science and Industrial Research Organisation (CSIRO) and University of Sydney. ${ }^{42}$ That computer, CSIRAC, had been developed for the radiophysics division of CSIRO, and was one of the earliest vacuum-tube storedprogram computers in the world. The meteorology department began using the computer for weather forecasting. One of the earliest masters students to use CSIRAC was Dick Jenssen, an avowed science fiction fan who had received 'spotty and inconsistent results' in his third year of undergraduate studies and was not expecting to be admitted to a masters program—suggesting, perhaps, that there was not a great student demand to undertake research training in glaciology and meteorology at the time. Jenssen, under Radok's instruction, used CSIRAC to run a barotropic model and make weather predictions..$^{43}$ Jenssen went on to receive a $\mathrm{PhD}$; after spending three years as an assistant professor at the University of Wisconsin, Madison, from 1963 to 1966, he returned to the meteorology department at Melbourne. ${ }^{44}$ CSIRAC stopped operation in 1964, replaced by a more up-to-date IBM, but certainly allowed for a certain view of the ice sheet and geophysical work in general in the meteorology department.

Computer modelling, therefore, became one of the sources of energy for Australian fieldwork. Drilling on the Law Dome and Amery Ice Shelf and the traverses would pump much-needed empirical data into the early computer models of ice dynamics. One of the glaciologists who so effectively used the computational power at the department's disposal—as well as being an excellent fieldworker at this time-was Loewe and Radok's student William (better known as Bill) Budd. Born in 1938 in New South Wales, he received his science degree at the University of Sydney, majoring in mathematics - there he had been a student of the world-renowned seismologist Keith Bullen. Very soon after beginning a career as a high school teacher, he joined the Australian Antarctic Division in 1960, and was the glaciologist at Wilkes Station from late 1960 to early 1962 . At the same time, he began postgraduate study with Loewe and Radok. After completing his MSc degree, as well as taking part in glaciological planning for ANARE, Budd returned to Antarctica as a glaciologist at Mawson Station in 1964 and 1965. In 1968, he completed his PhD and was appointed full-time to the Antarctic Division to lead its glaciological work, which he did until 1979, at which point he was appointed the foundation professor of meteorology at Melbourne. A short biography of him in 1976 described 'the central theme of his work' as the question ' $\mathrm{h}]$ ow does a large ice mass behave in real space and time?'45 Indeed, by the 1970s, Budd had established himself as one of the world's leading theoreticians and modellers of ice sheets.

42 Uwe Radok, Unimet - The Meteorology Department in the University of Melbourne (Melbourne: Meteorology Section, School of Earth Sciences, University of Melbourne, 1993), 11.

43 Dick Jenssen, 'My Life in SF Fandom', Challenger: A Science Fiction Fanzine 2005-06.

44 Jenssen, 'My Life in SF Fandom'.

45 'Bill Budd', Ice no. 51 (1975): 10-11; 'Seligman Crystal Award 1996. Dr William F. Budd', Ice no. 111/112 (1996): 15-21. 
The work of Budd, Radok and Jenssen created a virtual whole ice sheet in the Melbourne computer, and in the process truly cemented Melbourne's place as a leading glaciological centre. Though their work was published throughout the decade, the significant articulation of it came in 1971, with the monograph Derived Physical Characteristics of the Antarctic Ice Sheet. In that work they stated their principal aim: to calculate 'various unknown physical characteristics of the Antarctic Ice Sheet as a whole, from the data available. These characteristics include the temperature and velocity distributions, the age of the ice, the particle paths and patterns of flow, and the state of balance'. ${ }^{46}$ It is clear that Radok had a high regard for the computational and modelling work of his department; indeed, he stated that these models would guide others to situate their fieldwork in particular ways. ${ }^{47}$

By around 1970 then, the glaciology program of the Melbourne meteorology department and the Australian Antarctic Division (conjoined and overlapping institutions, it must be remembered) had grown from small, if auspicious origins, to become a premier centre of Antarctic glaciology in the world (though still small, to be sure). As interpreters of the Antarctic ice sheet, Radok, Budd and their colleagues were in possession of strategic sites in the field-the Amery Ice Shelf and Law Dome_-as well as the intellectually significant site of the computer-generated model of the 'derived' or virtual ice sheet. If the fieldwork helped to instantiate Australian sovereignty over the ice sheet, the derived, modelled ice sheet was perhaps less conducive to Australian sovereignty, though important for Australian standing and authority, both scientifically and politically.

\section{Territoriality and internationalism}

By the late 1960s, knowledge of the Antarctic ice sheet had advanced considerably. Traverses, fieldwork, early computer work and theoretical and conceptual developments were all fleshing out the contours of the ice sheet. But there were still great gaps in knowledge. ${ }^{48}$ This period also marked a turning point in several areas. Locally to Australia, ANARE glaciology became organisationally independent of the Melbourne University meteorology department in 1970, though it remained co-located for a time. ${ }^{49}$ At the international scale, from 1968, plans emerged for a concerted glaciological program among the relevant Antarctic states. This crystallised into the International Antarctic Glaciological Project (IAGP). These two

\footnotetext{
46 W. F. Budd, D. Jenssen, and U. Radok, Derived Physical Characteristics of the Antarctic Ice Sheet (ANARE Interim Reports, vol. 120) (Melbourne: Antarctic Division, Department of Supply, 1971), xiv.

47 U. Radok, Letter to M. I. Homewood, 4 July 1969. B1387, 1986/576 Part 1, NAA.

48 Two great products of the mid-1960s articulated both the advances in knowledge and the gaps: C. R. Bentley, R. L. Cameron, C. Bull, K. Kojima and A. J. Gow, Physical Characteristics of the Antarctic Ice Sheet, ed. Vivian C. Bushnell, (Antarctic Map Folio Series, 2) (New York: American Geographical Society, 1964); and 'Atlas Antarktiki' [Vol. 1], Soviet Geography: Review and Translation 8, no. 5-6 (1967).

49 Radok, Unimet-The Meteorology Department in the University of Melbourne, 21.
} 
developments saw the ice sheet become the subject (in both a renewed and novel sense) of territoriality and internationalism. The Australian program could make the ice sheet meaningful as a body for nationalistic enterprise, at the same time as the IAGP (with Australia a member) could internationalise, indeed globalise, the ice sheet. And by straddling particular aspects of the sheet and its breadth, Australian efforts within the IAGP authored the ice sheet and authorised Australian presence.

In September 1968, the Scientific Committee on Antarctic Research (SCAR) Working Group on Glaciology and the International Association of Scientific Hydrology Commission on Snow and Ice convened a major conference on Antarctic glaciology at Dartmouth College in the United States, titled the International Symposium on Antarctic Glaciological Exploration (ISAGE). With 125 glaciologists and geophysicists present and 60 papers presented, the conference was perhaps the largest such gathering to date. Although the great majority were Americans, the number of glaciologists present spoke to the significant developments in the discipline, especially for Antarctica, over the previous decade. ${ }^{50}$ The conference was a turning point. Radok described it as 'the first comprehensive review of our knowledge about the Antarctic ice sheet and of techniques for its exploration'. ${ }^{51}$ There was also the thrill of incipient and new research: there were reports on the ice-core drilling conducted at Byrd Station (1966-68) and the beginnings of radio-echo sounding.

This conference also hosted planning meetings for future research. A year earlier, scientists from France, the Soviet Union and the United States began discussing joint glaciological work in East Antarctica, specifically in the region bordered, generally, by the American McMurdo, the Soviet Vostok and the French Dumont d'Urville stations. While the IGY traverses had been extensive in West Antarctica, the East Antarctic Ice Sheet-by far the bulk of the whole Antarctic ice sheet-had remained under-studied. The 1968 ISAGE conference saw these ideas form into a concrete program to study the ice sheet between $90^{\circ}$ and $160^{\circ}$ east, with Britain and Australia joining the effort - the program became known as the International Antarctic Glaciological Project. ${ }^{52}$ In the French proposals for the IAGP, the program was envisaged as a study of the 'natural conditions prevailing on that continent, which have an influence on the planetary scale'. ${ }^{53}$

By May 1969, the participating countries had agreed to a project outline. The aims were 'determining the glaciological regime and processes, and deducing some of the history and future, of a sizeable part of the East Antarctic ice sheet'. It described

50 H. Hoinkes, 'International Symposium on Antarctic Glaciological Exploration, 1968 (ISAGE)', SCAR Bulletin no. 34 (1970): 138-40.

51 U. Radok, 'Report on Overseas Trip', 14 October 1968. B1387, 1986/576 Part 1, NAA.

52 Hoinkes, 'International Symposium on Antarctic Glaciological Exploration, 1968', 140.

53 'French Proposal for a Scientific Program', 9 April 1968. B1387, 1986/576 Part 1, NAA. Simone Turchetti and colleagues have given some attention to the IAGP, particularly emphasising the logistical impetus and promise of the program, and the centrality of US logistical prowess in the whole endeavour: Turchetti et al., 'On Thick Ice'. 
the ice sheet as 'a record of precipitation', containing 'unique information on the terrestrial and extra-terrestrial environment; it also plays an important boundary role for the atmospheric and oceanic circulations'. The project aimed:

to clarify the relationships among the size, shape and glaciological regime of the ice sheet; to reconstruct various stages of its development, their causes, and their effects on the atmosphere and the world ocean; to assess the relationships between the ice sheet and changes in climatic conditions; to determine any changes in size and regime taking place at the present time; and to trace events of human and natural origin recorded in the ice. ${ }^{54}$

These questions would be addressed through several methods. First, the IAGP envisaged an extensive traverse program, with a significant range of geodetic, geophysical, seismological and other physical and chemical measurements. Second, there would be an airborne radar (radio-echo) sounding program. Third, there would be deep drilling and ice core studies. And finally, observations would be made at the ice margins through aerial photography and ground studies. ${ }^{55}$ The program, in short, combined both the demands of basic survey and observation that had been a part of glaciological research from the beginning, with the new technologies and approaches of radio-echo sounding and deep ice-core drilling. Later in the planning, it became an explicit element of the IAGP that this data collection would be fed into theoretical models (especially those developed by Radok, Budd and Jenssen in Melbourne), and that the models could guide data collection efforts, to aid a greater understanding of the ice sheet's past and future and its processes. ${ }^{56}$

The advent of the IAGP was both a challenge to and confirmation of Australia's Antarctic position. With few resources, but significant intellectual inheritance and power, the Australian Antarctic Division had fashioned a respectable, indeed significant, glaciological program-it had clearly helped construct the contemporary idea of the ice sheet. Radok, as SCAR representative rather than as Australia's representative, was invited to take part in the inaugural IAGP meeting in early 1968; he described that invitation as 'both a concession and a compliment to Australia's standing in Antarctic glaciology. ${ }^{57}$ Radok wanted Australia to join this effort. He saw it as 'a unique opportunity for getting our program aligned with the major new development in Antarctic research and for laying the basis of future cooperation, with all the resulting logistic and other benefits. Nothing quite like it will recur'. ${ }^{58}$ Radok saw a confident position for Australia in the IAGP because of its

54 'International Antarctic Glaciological Project', SCAR Bulletin no 38 (1971): 830.

55 'Details of discussions held at the Institute Geographique National and the office of the Expeditions Polaires Francaises, Paris, 27-29 May, 1969'. B1387, 1986/576 Part 1, NAA.

56 Charles R. Bentley, 'International Antarctic Glaciological Project', Antarctic Journal of the United States 7 (1972): 50. Paul Edwards gives close attention to the relationship of data and models for atmospheric and climate sciences in A Vast Machine: Computer Models, Climate Data, and the Politics of Global Warming (Cambridge, MA: MIT Press, 2010).

57 U. Radok, Letter to P. G. Law, 26 March 1968. B1387, 1986/576 Part 1, NAA.

58 U. Radok, Letter to D. F. Styles, 19 March 1968. B1387, 1986/576 Part 1, NAA. 
particular perspective on the ice sheet. In a letter to a senior Australian bureaucrat he reflected that, while Australians were sometimes 'overawed ... by the logistic resources of the American and Russian expeditions', scientists in those and other countries 'have an obvious respect' for the Australians, especially given that it was the Australians who had the 'mathematical equations' that might very valuably show 'the way to new meaningful measurements' . 59

Yet others were not as welcoming as Radok. From a geopolitical perspective, an Australian diplomat stated that 'we ought to discourage the concentration of a major international Antarctic scientific program in any limited area of Antarctica (especially within our territory) unless there are sound scientific reasons to the contrary'. That officer went on to suggest that any international scientific cooperation should be 'carried out on continental basis so as to avoid an unbalanced emphasis on one area (which in this case happens to be Australian Antarctica)'. ${ }^{60}$ In an internal Australian meeting on IAGP proposals, that diplomat 'noted that scientists are also political animals, and that Russia and the United States have as a political aim the complete internationalisation of Antarctica or, alternatively, the making of claims at the expiration of the Treaty'. ${ }^{61}$ Some officials saw the IAGP plans as a slight, in that these international scientists did not recognise the Antarctic ice sheet as a legitimate site of Australian endeavour - or that Australian endeavour did not meaningfully constitute the Antarctic ice sheet for others. In both the geopolitical and disciplinary environments, the ice sheet was not an easy or frictionless site for projecting or carrying Australia's identity and aspirations for territorial occupation.

Whether a compliment or challenge to Australia’s glaciological standing, Australia did join the IAGP officially soon after its inception. Luckily, the IAGP did not demand a fundamental change of ANARE's and the department's plans, which remained focused on existing areas of strength. The project would allow Australian scientists and their government to manifest a certain territoriality of the ice sheet within an international framework. ${ }^{62}$ In the first half of the 1970s, ANARE concentrated its fieldwork on the 'flowline' between Casey and Vostok stations, and on investigating the Wilkes Ice Cap-Vostok Station was also the site of Russian ice-core drilling efforts with French analytical research, which, by the late 1980s, had led to some of the earliest compelling evidence of the links between atmospheric carbon dioxide levels and temperature. The flowline work concentrated on tracing the paths of ice particles from the sites of their deposition high on the ice sheet to their sites of calving and wastage. In the late 1970s, Australians also joined Soviet

59 U. Radok, Letter to M. I. Homewood, 4 July 1969. B1387, 1986/576 Part 1, NAA.

60 G. Coles, Telegram to M. I. Homewood, 22 April 1969. B1387, 1986/576 Part 1, NAA.

61 'Notes on discussion at meeting on A.N.A.R.E. glaciology. Held at 568 St. Kilda Road-24th April, 1969'. B1387, 1986/576 Part 1, NAA.

62 In this assessment, I depart somewhat from the analysis of Turchetti et al., which argued that the promise of logistical support was important for enrolling Australia into the IAGP. Turchetti et al., 'On Thick Ice'. 
traverses between the coastal Mirny Station and Dome C (see Figure 1 for a general outline of Australian traverse routes during the IAGP). The other participants also proceeded with their own work. The airborne radio-echo sounding was particularly active. $^{63}$

Of Australia's fieldwork, the multi-season traverse of the 2,000 m contour line is noteworthy. Having successfully traversed inland to Vostok, from the 1974-75 season Australian glaciologists began planning a massive traverse effort across the breadth of the ice sheet; in fact, the Australian glaciologists seemed to be the only ones interested in providing this 'cross-basin' effort. ${ }^{64}$ The choice of the $2,000 \mathrm{~m}$ contour line was mostly pragmatic. A traverse nearer the coast, along a lower contour, would have had a more variable and difficult time, while the 2,000 m contour was a good deal straighter and easier to navigate; in any case, the traverses were never strictly only along that contour. ${ }^{65}$

Although there were five IAGP participating nations, only the Soviet Union had a ground-traverse program as extensive as Australia's. Indeed, the Australians and Soviets joined forces on four major traverses during the program. Britain and United States concentrated on airborne radio-echo sounding, and the French concentrated their efforts drilling at Dome $\mathrm{C}$. The traverses differed from radio-echo sounding and drilling because they were designed to be repeated in the shorter term. The markers laid down on the routes had to be remeasured to assess the movement of the ice, whereas the drilling at Dome $\mathrm{C}$ was arguably one-off, and the radio-echo sounding, though certainly repeatable, was intended, over the course of a few years, to reveal the thickness of the whole ice sheet-culminating in a major cartographic depiction. The Australians, and the Soviets to a different degree, valued, indeed demanded for both scientific and territorial reasons, mobility and marking of the ice sheet.

63 On the specific institutional pressures and incentives behind radio-echo sounding, see Dean et al., 'Data in Antarctic Science and Politics', and Turchetti et al., 'Accidents and Opportunities'.

64 Minutes of IAGP Council Meeting, 10 December 1979. B1387, 80/136 Part 2, NAA.

65 W. Budd, November 2015, personal communication. 


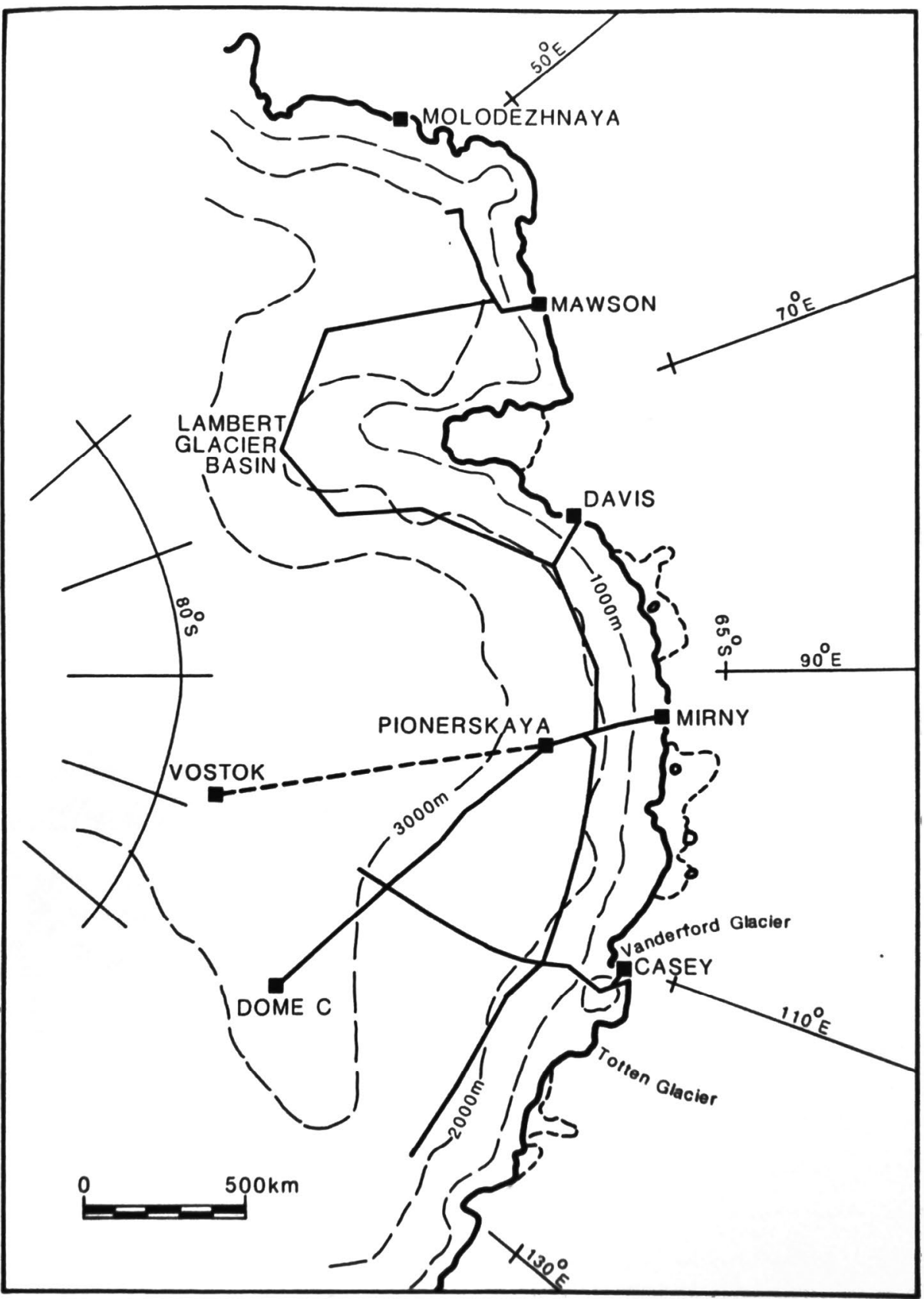

Figure 1: The general outline of completed and proposed traverse routes by the Australian National Antarctic Research Expeditions (ANARE)-some in partnership with international colleagues-for the International Antarctic Glaciological Project (IAGP), along flowlines and the 2,000 m contour line

Source: N. W. Young, 'International Antarctic Glaciological Project, Australian National Report 1985', 7 August 1985. B1387, 85/333, National Archives of Australia. 
While the traverse efforts began in an internationalist spirit, by the 1980s, the rhetorical emphases of the traverses morphed, as the ice sheet became more firmly a site of nationalist and geopolitical contest, as well as increasingly a 'global' object. In 1984, the ANARE glaciologist Neal Young described the traverse program as 'the Division's most visible and unique activity on the continent. It has a direct application in expression of sovereignty as well as producing results used in glaciology and other disciplines' ${ }^{66}$ As well as the resurgent vision of a plane of sovereign contest and assertion, the ice sheet was also enrolled as a resource-filled body into the main exploitation narratives of the 1980s. In an article titled 'Australia's Interest in the Antarctic Ice Sheet' in 1986, Bill Budd enumerated 'the unique assets of Antarctica', concentrating on the environmental and data resources contained in the ice sheet. ${ }^{67}$

The IAGP was initially planned for a (flexible) 10-year period, though it did extend into the 1980s. In the early 1980s, it began to morph into other international research efforts, including the World Climate Research Programme, suggesting how the ice sheet was becoming a more global object connecting to questions of climate. ${ }^{68}$ In 1985 , with the IAGP mostly passed, Radok could write that Antarctica could 'even today' be described as 'terra incognita'. ${ }^{69}$ While he could confidently state the basic contours of the ice sheet-drawn especially from the airborne radioecho sounding work-he could not make any great statements on the ice sheet's regime; though he could state that it was Australian traverse work, alongside Russian counterparts, that had helped to provide answers to regime questions.

\section{Conclusion: The tensions between glaciological bodies}

At least two major turning points for Australian glaciology in the late 1980s and early 1990s mark an appropriate conclusion for this article's story. First, the Cooperative Research Centre for Antarctic and Southern Ocean Environments (the Antarctic CRC) was established in Hobart in 1991, about 10 years after the Australian Antarctic Division had moved to Hobart after many decades based in Melbourne. With the CRC's creation, Budd and other glaciologists moved to Hobart to participate in the interdisciplinary work there. ${ }^{70}$ Second, the IAGP was

\footnotetext{
66 N. Young, Memorandum, 10 September 1984. B1387, 80/612, NAA.

67 Bill Budd, 'Australia's Interest in the Antarctic Ice Sheet', Aurora: ANARE Club Journal 6, no. 2 (1986): 3-4. It needs to be mentioned that at the beginning of the 1980s a new structure of scientific advice and government policy was instituted for Australian Antarctic science. One of the early recommendations of the Antarctic Research Policy Advisory Committee was to contract out glaciology work to the University of Melbourne as it was not a scientific discipline that centrally advanced the investigation of living and mineral resources in the Australian Antarctic Territory.

68 See Deputy Director Research, Memorandum, 5 October 1981. B1387, 80/136 Part 2, NAA.

69 Uwe Radok, 'The Antarctic Ice', Scientific American 253, no. 2 (1985): 98.

70 See Cooperative Research Centre for Antarctica and the Southern Ocean, Southern Quest: A journey of discovery for Australian Antarctic science (Hobart: Antarctic CRC, 2003).
} 
well and truly over, with Antarctic science entering a more globally focused and interdisciplinary phase, in which Australian scientists were enthusiastic and leading participants. ${ }^{71}$

The story of these mutual engagements of glaciological bodies-Australian-based glaciologists and the Antarctic ice sheet-offers three tensions to consider as a way forward for considering not only ice but other elements and materials of the global environment. First, it is worth considering the variable centrality of the ice sheet in this story. That is, the ice was sometimes a central object of concern and sometimes it seemed little more than a stage for governmental or individual effort. Potentially mineral-bearing rock and marine populations were often of more interest to the Australian Government, though not of course to the glaciologists. The irony of this tension, given that the Antarctic ice sheet is the largest body of ice on earth and the feature that defines the Antarctic environment is, of course, notable. Second, there is a tension of embodiment and abstraction, the view of the ice sheet from a very specific, material place or from the enumerated and data-rich perspective of the 'ticking robots' (as Loewe would put it), the computer models and their equations. While the fieldwork heroics were often valorised professionally and in the media — and therefore leading to a particular perspective on knowing the ice-more abstract ways of seeing the ice were less valorised. And, finally, there is a tension between a small or localised view of the ice sheet, and one of the whole ice sheet. If, from a scientific perspective, both scales were (and are) needed, geopolitics has often demanded control and expansiveness across the whole sheet.

Each of these tensions is suggestive for challenges in the present. Intellectual and affective relationships with ice might become more important and simultaneously more troublesome, given that continuing and accelerating global environmental change means a diminished cryosphere. While computer models and forecasts are demanded by policy-makers and scientific forecasters, the political will and energy generated by affective relationships with place are difficult for sites where permanent human settlement is difficult and historically sparse or non-existent. The Australian experience of glaciology and the Antarctic ice sheet suggests stories and resources that might be drawn upon, but also the challenges of constituting and living with glaciological bodies.

71 For a representative articulation of this shift, see Richard Fifield, International Research in the Antarctic (Oxford: Oxford University Press for the Scientific Committee on Antarctic Research and ICSU, 1987). 
This text is taken from International Review of Environmental History, Volume 4, Issue 1, 2018, edited by James Beattie, published 2018 by ANU Press, The Australian National University, Canberra, Australia.

doi.org/10.22459/IREH.04.01.2018.09 